\title{
Musical styles approached by Serbian composers in the first half of the 20th century
}

\author{
Virginia TOTAN ${ }^{1}$
}

\begin{abstract}
The musical creation of Serbian composers is not well known in the European area, primarily due to censorship in the first half of the 20th century when music influenced by European orientations was considered capitalist and was banned on the one hand, and on the other hand due to the fact that most of the works are written in Cyrillic and thus did not reach the European research circuit. It should be mentioned that the course of development of music history in Europe, with its periodization into stages of Baroque, Classicism, Romanticism, Impressionism, Expressionism, Neoclassicism, Avant-garde and Postmodernism, was not applied to music in Serbia. However, all these styles will be found in the musical creations of Serbian composers in the period from the end of the 19th century and during the $20^{\text {th }}$ century.
\end{abstract}

Key-words: Rukoveti, Mokranjac, 20th century

\section{Introduction}

"Serbian music developed in the Balkans over a long period of time, which can be seen in two basic stages - Old Serbian art, whose development is traced from the time of the immigration of the Slavic tribes until the 18th century, when there was a strong penetration of Western-European influences, and modern art, which began with the influence of Romantic ideas in the 19th century and lasts until the present." (Šuvaković, Pejović, Veselinović-Hofman 2008, 15).

For more than a century - from the 1930s to the middle of the 20th century Serbian music developed within a romantic framework. „Its evolution can be seen through three basic stages: pre-romanticism (until the early eighties), romanticism -

\footnotetext{
1 PhD Scholar, Transilvania University of Brașov, Faculty of Music, totan.v97@gmail.com
} 
the emergence of Mokranjac (until 1914) and late romanticism - the path to modernism (until the early fifties)" (Marinković 1999, 24). In that long period of development, it moves from laying the foundations of art music (in the European sense of the term) to shaping a clear identity of a rich, branching musical tradition that is actively involved in the worldwide development of contemporary music. At the beginning of the fifties of the twentieth century, Serbian music entered a new stage of development, which is characterized by an extraordinarily layered stylistic picture and a significant contribution of numerous composers that will be seen through the presentation of trends in the development of Serbian music after the fifties.

\section{Discussion: The musical styles of the Serbian composers}

With this research I want to expose the main compositional styles that are found in the cult of the Serbian music of the first half of the twentieth century, because it is a less researched field. In terms of my biography, I am close to this stylistic space, because I have had access to information resources stored in archives, resources that allow me to detail this topic. This stylistic research of the music of the communities that are also around Romania and that have reverberation in the western part of Romania, is topical research due to the fact that today much emphasis is placed on multiculturalism, on knowing the ethnic and musical characteristics of each people. Pre-romanticism manifested itself in Serbian music very comprehensively and clearly in the period between the thirties and the early eighties, when two important personalities such as Mokranjac and Marinković appeared, who with their work founded national romanticism.

However, pre-romanticism would lose its dominance in the time of Mokranjac and therefore the eighties, when his and Marinković's intensive creative work began, can be considered a turning point in the development of Serbian music and which also marked the beginning of a new stage of development. In music, the typical forms of manifestation of these aspirations were: stage music, solo singing, choral music - that is, mostly vocal and vocal-instrumental creations. Such a genre orientation of creativity is determined by the degree of development of the institutions of musical life. At that time in Serbia the process of their establishment began with the founding of theatres and singing societies, under the auspices of which the sparks of future pedagogical institutions of musical life were set, as well as the organisation of the first public concert performances. Stage music was the most popular genre in the middle of the 19th century, where it can be noted that music played an extremely important role in it, but this part of the 
Serbian musical heritage is largely inaccessible today, as manuscripts are either lost, or in a very poor, often illegible, condition. The earliest preserved compositions of Serbian music from this period are harmonisations and arrangements of folk songs. The period that includes the end of the 19th century and the beginning of the 20th century in Serbian culture in all fields, even in music, brought essential, major changes in the European space, relevant results in art and science.

In those thirty years of intensive development, the material basis for the development of European-style musical life was built. Institutions were established: the National Theatre (1868) developed its activities, in which musical and stage operas were performed, as well as other plays and operas (Opera on Žarko Savić Boulevard, 1909-1911, plays in Novi Sad, Niš, Šabac; ensembles with numerous choirs, various orchestral and chamber ensembles were established, important soloists - singers and conductors appeared. With the establishment of the Serbian School of Music in Belgrade (1899), the foundations of music education were laid, and a little later the establishment of the Isidor Bajić School of Music in Novi Sad (1908) and the Stanković School of Music in Belgrade (1911) led to the development of music publishing.

Several generations of composers worked during this period.

"In the eighties the creative work of Mokranjac and Marinkovic began, at the beginning of the 20th century Binički, Krstić, Paunović, Bajić and Đorđević, and in the years before the First World War the first compositions were written: Konjović, Milojević and Hristić. In a stylistic sense, Pre-Romanticism, Early Romanticism and Late Romanticism meet and intertwine, and in a genre sense, it is a period in which operas of all genres are composed - with the most common being vocal music (choral and chamber - solo song) and instrumental - symphonic and chamber music, as well as operas." (Šuvaković, Pejović, Veselinović-Hofman 2008, 143)

The most important personality of the late 19th and early 20th century, and I consider also for the history of Serbian music in general, was Stevan Stojanović Mokranjac (1856-1914), whose work can be compared and equated with the importance of Vuk Karadžić in Serbian literature. Just as Karadžić's period represents the beginning of Romanticism in Serbian literature, so Mokranjac founded Romanticism in music and with his work laid the foundations for the development of the national school of composition. Having completely mastered his professional skills and brought Serbian musical tradition to a higher level, with 
the beauty of his works, the exceptional strength and conviction of his artistic expression, he was a model that future musicians would later respect and cultivate.

"Mokranjac is in many ways a typical representative of the first generation of Romanticists - the founder of the national school - in the interest of not only his own folklore, but also that of other peoples (Macedonian, Bosnian, Russian, Hungarian, Romanian, even Turkish), as well as in the way he approaches it - through aestheticization and stylization as a beginning process in the processing of folk melodies" (Ilić 1994, 3).

Mokranjac's knowledge and understanding of folklore is essentially different from pre-Romantic - he did not have his first contact with folk songs in printed material. The folk tradition was already present in the first sound impressions of his childhood. In his works, he addresses it as an artist-romanticist, aestheticizing folklore, abandoning the important laws of folk tradition life moving the melody out of the folk context and freely mixing the definition of the genre and the original structure of the melody, stylizing it according to the ideal of classical beauty. Aesthetics imposes certain limitations on the knowledge and assimilation of the folk tradition, but nevertheless opens the way to the rich influences of folklore on the development of all parameters of the musical language - melody (the thematic component was of primary importance for the Romantics), but also rhythmic, agogic, musical form, harmonic thinking, genre enrichment. The path of transformation of folklore for the Romanticists of this generation was not a path determined by a system of rules to be followed: it is the fruit of Mokranjac's individual quest, like that of other composers of Romanticism, marked with the stamp of genius, and therefore for future generations it is a model and inspiration and will be accepted as a necessity and legality. Mokranjac's founding significance for Serbian music unequivocally confirms the path of Rukoveti's development in Serbian choral music, as well as the influence of conducting as a specific mode of musical thinking on the development of instrumental and choral forms.

"Mokranjac's work was very diverse. He worked in several fields: conductor of the Belgrade Singing Society (and many other societies), pedagogue (he was one of the founders of the first permanent music school in Serbia in 1899, known today as the Mokranjac School in Belgrade, where he taught at the theological high school and secondary school), ethnomusicologist (he collected folk melodies and was the first to publish authentic folk melodies in 
one voice, without processing and harmonization). He notated church songs (Belgrade version of Serbian church songs, published Osmoglasnik in 1908 and prepared Strano pjenije for printing in 1914, but the manuscript was lost during the war, which was later rewritten and published by Kosta Manojlović in 1935." (Ilić 1994, 5)

Mokranjac's compositional opus is still considered one of the most important achievements of Serbian art music even today. In terms of genre, it focuses on vocal music, mostly choral. Mokranjac's works in the field of spiritual and secular music are of equal significance, although his contribution to the music of the Orthodox spiritual tradition is much greater. His spiritual works belong to the main achievements of the world heritage (Opelo in F minor - 1888, Liturgy of St. John Chrysostom - 1895, Dve pesme na Veliki petak 1892-93, Tebe Boga hvalim 1904, Tri statije na Veliku subotu 1904-07.). They are imbued with the spirit of traditional singing, mostly based on folk spiritual songs, performed by a connoisseur of choral creation, inspired, especially with modal harmonies, rich, diverse polyphony. They are simultaneously an intimate and profound expression of sincere faith.

In the field of secular music, Mokranjac's work focuses on vocal creation, more specifically on the choral tradition. In this field, the main place in Mokranjac's opus is occupied by Rukoveti, choral rhapsodies composed from a series of songs he collected from the people. Mokranjac chose his name for his works using a beautiful Serbian word (which has the meaning of a wreath - a bunch of flowers picked from the field) and thus emphasised a close connection between musical thought and folk art. Forms similar to those in Rukoveti are also known in the European musical tradition (both in vocal and instrumental music) and in Serbian music of that time this form was often found under other names - venci, kola, spletovi pesama. Such works are simply processed. Mokranjac, with Rukoveti far surpassed his predecessors and created masterpieces of unrepeatable beauty and distinctly individual romantic concepts. 

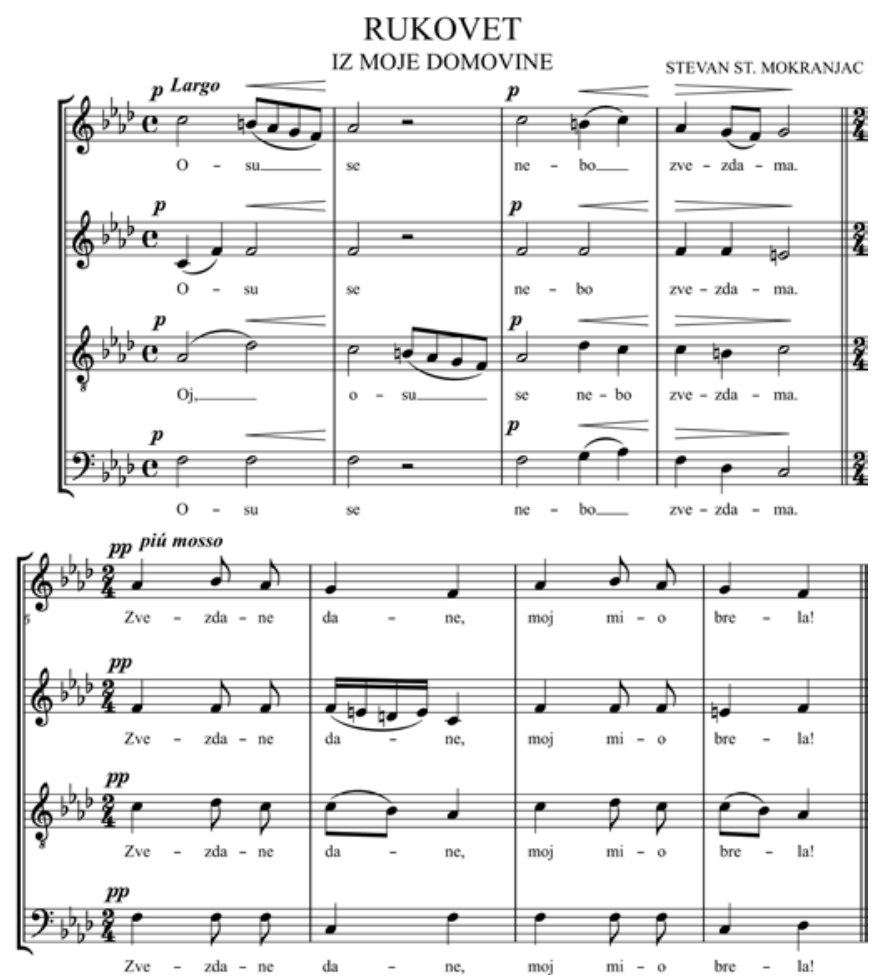

Fig. 1. Rukoveti II - "Stevan Stojanović Mokranjac"

„Rukoveti is characterized by an excellent choice and careful combination of musical material, a refined sense of the unity of poetic and musical ideas, a complete musical-dramaturgical conception of the work, an extraordinary texture of choral attitude, a rich palette of means of expression, especially in harmonic language" (Marinković 1999, 52).

With his modal conception of harmony, Mokranjac laid the foundations of the national harmonic style. Mokranjac's Rukoveti are often perceived as a kind of anthology of folk songs, but the authentic origin of the melodies can be determined today for only forty of the 80 songs from which the Rukoveti are created. This fact has not significantly affected their perception: all the songs are accepted as the quoted processing of folk songs, and the way of working with folk material is considered exemplary: knowledgeable in terms of professional knowledge, as well as excellent in understanding the spirit of folk art. 
„Notable in this respect are the fifth (1892), sixth (1892, with poems about Hajduk-Veljko), tenth (1901) and fifteenth Rukoveti (1909). The first Rukoveti are characterized by a large number of songs (up to ten) based on Serbian folklore - the first Rukoveti (1883) the sixth and thirteenth (1907) are called Iz moje Domovine (From My Homeland). The seventh (1894) and eleventh (1905) contain poems from Old Serbia; the eighth (1896) and twelfth (1906) are made up of songs from Kosovo; the ninth (1896) from Montenegro; and the tenth and fifteenth from Macedonia" (Marinković 1999, 64).

To the type of Rukoveti also belong Primorski napjevi (1893). Compared with Rukoveti, Mokranjac's other works in the field of secular music, with the exception of the brilliant choral scherzo Kozar (1904), are less well known and accepted.

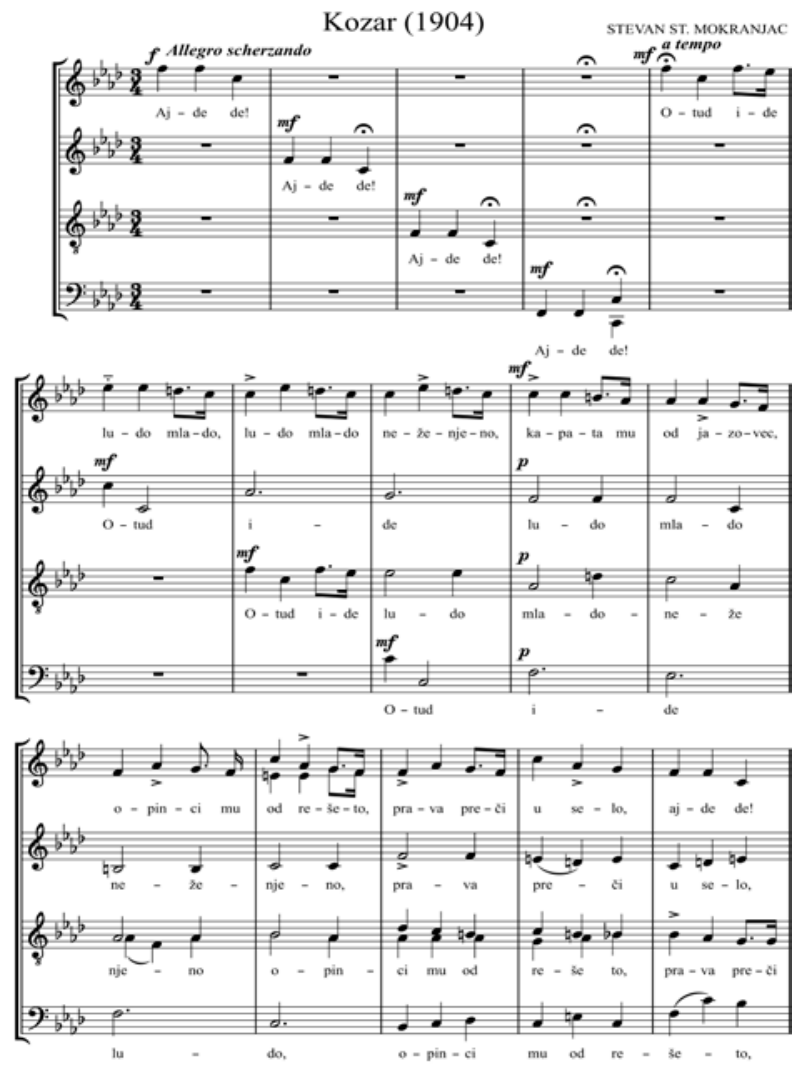

Fig. 2. Kozar - Stevan Stojanović Mokranjac 
In Serbian music, the Rukoveti played the role of a rich treasury from which the works of future generations of composers were inspired. In this respect, the connections between Rukoveti (the songs Lele, Stano mori and Cveće cafnalo) and the first Serbian symphony - Konjović's Symphony in C minor, as well as the tenth Rukoveti with Hristić Ohridska's ballet Legenda are most often mentioned. But the themes of these works, as well as their compositional principles, have been used many times, which determines the specific position of Mokranjac's work in the Serbian musical tradition as a basis and turning point.

At the beginning of the 20th century, a generation of composers began their work, which in the history of Serbian music has been called the Belgrade School. This name symbolically underlines the fact that at the beginning of the century there was a strong centralization of musical events and that Belgrade became a true centre of Serbian musical culture, because the best musicians worked there. The creative contribution of the composers of the Belgrade school, even though the composers' appeal to folklore in a stylistic sense can be assessed as regressive, as it goes back to the pre-Romantic experiences of that area, is significant for Serbian music as a change of genre. The first operas and symphonic works appear in their creations, and their organisational, performance and pedagogical activities, as well as the work of collecting folk tunes, are based on reliable professional foundations they acquired during their schooling in leading European musical centres - Munich, Prague and Vienna.

The most prominent creative person among the composers of the Belgrade School was Stanislav Binički (1872-1942), an important organizer, conductor, and teacher, one of the founders of the Serbian School of Music, later the first director of the Stankovic School, conductor of the first Serbian symphony orchestra (the Belgrade Military Orchestra in 1899-1904, which in 1904 was renamed the King's Guard Orchestra), as well as choral ensembles. He was the first director of the Belgrade Opera (1920-1924) . Binički's opera Na uranku, was the first Serbian opera performed in 1903 at the National Theatre in Belgrade, composed in the spirit of the romantic opera tradition with verismo influences, but in a national context (the action takes place in a Turkish-occupied village). Binički also composed numerous other orchestral overture works (Iz mog zavičaja) and military marches (Marš na Drinu); music for plays; choruses (Seljančice and Tetovke which were particularly successful); spiritual compositions (Liturgija and Opelo) and solo songs (cycles of Songs of Southern Serbia and Mijatovka)."(Marinković 1999, 63)

Modernist impulses found unprepared ground in Serbia, which is not unusual given the circumstances of the position of musical culture in general in our country at the beginning of the 20th century. At that time, the youngest generation of 
composers, who would mark the later, interwar period of Serbian music, with Petar Konjović (1883-1970), Miloje Milojević (1884-1946) and Stevan Hristić (1885-1958) as their most prominent representatives, had the greatest affinity for music, a legacy of late Romanticism which they integrated into their own works, occasionally enriching it with elements of Impressionism and, rarely, Expressionism. Probably Milojević's solo songs Nimfa (1908) and Japan (1909) are the first Serbian compositions in which, in addition to elements of verismo and Strauss's lavish chromaticism and dramatic expressiveness, the influences of impressionism are noticeable, so we can consider them the first hints of modernism in Serbian music.

"The composers of this generation saw themselves as "revolutionaries", more precisely as "expressionists", who used the elements of modernity, exploiting those elements with constructive experience. Starting from the foundations laid by the composer Stevan Stojanovic Mokranjac, with full respect for the achievements of his art, they strive to bring Serbian music closer to contemporary European artistic trends in style and genre." (Jovanov 1999, 47)

From the beginning of the 20th century until the First World War, when musical life in Serbia was dominated by Stevan Stojanović Mokranjac, the composers Konjović, Hristić and Milojević, had time to insinuate their true potential, and one of them aroused the domestic musical public: after the premiere of Hristic Vaskrsenje's oratorio (1912), critics reacted negatively not only to the modernization of the musical language itself, but also to the fact that the elements introduced by verism and impressionism were, according to them, inappropriate themes of the oratorio. They, and above all Milojević, were disturbed by the absence of national, Serbian symbols, so they evaluated the innovative elements in the work as "foreign".

\section{Conclusions}

As in other musical nations where at least one stream of composers sought to build a recognisable 'national style', there was tension, more or less pronounced, between 'nationalists' and 'cosmopolitans' among Serbian composers for several generations. The works of these three composers point to a late Romantic style and will form the basis of their future work and subsequent stylistic development towards the Impressionist and Expressionist styles, styles which will be manifested in works created between the two world wars. 


\section{References}

Despić, Dejan. 1999. Harmonic Language and Choral Texture in Mokranjac's Works, in: Complete works of Stevan Stojanović Mokranjac, vol. 10. Beograd Knjaževac: Institute for textbooks and teaiching aids, Music publishing administration Nota.

Ilić, Vojislav. 1994. Preface to the Liturgy. Complete works of Stevan Stojanović Mokranjac. Belgrade: Institute for education.

Marinković, Sonja. 1999. Citation polemic in the Serbian choral music inspired by folklore. Belgrade: New sound.

Marinković, Sonja. 2000. History of Serbian music. Belgrade: Institute for education.

Šuvaković, Miško, Roksanda Pejović, Mirjana Veselinović-Hofman. 2008. History of Serbian Music: Serbian Music and European Music Heritage. Belgrade: Institute for education Belgrade. 